\title{
How to Judge Safety \\ Crime: Lessons From \\ the Eternit Asbestos \\ Maxi-Trials
}

NEW SOLUTIONS: A Journal of Environmental and Occupational Health Policy $0(0) 1-19$

(C) The Author(s) 2019

Article reuse guidelines: sagepub.com/journals-permissions DOI: | 0.1 | 77//|04829| | | 9852420 journals.sagepub.com/home/new

SAGE

\section{Pascal Marichalar' (D)}

\begin{abstract}
When it comes to occupational injury, disease, and fatalities, criminal prosecution and punishment is the exception. This paper focuses on three loopholes in legal strategy that make it difficult for determined social movements and committed prosecutors to secure conviction against corporate executives: they are the notions (I) that "modern" industrial risk is by essence impersonal and diluted, making the assignment of individual responsibility difficult or impossible, (2) that industrial hazard is foreign to any notion of intention, fault or responsibility, (3) that the certainty of the causal link between exposure and damages must be established for each victim on a purely individual, rather than statistical, basis. I describe how Italian prosecutors sought to circumvent these loopholes in the Eternit asbestos maxi-trials. Although there appear to be solid legal workarounds for the first and second loophole, the third one remains problematic, calling for urgent political and legal imagination.
\end{abstract}

\section{Keywords}

occupational disease, criminal law, asbestos, Italy, epidemiology

\section{Introduction}

When it comes to employer responsibility for failing to prevent occupational injury, disease and fatalities among employees, criminal prosecution and

'CNRS, EHESS, Paris, France

\section{Corresponding Author:}

Pascal Marichalar, CNRS, EHESS, 54 Boulevard Raspail, Paris 75006, France.

Email: pascal.marichalar@cnrs.fr 
punishment is the exception. ${ }^{1}$ Institutions that treat situations of worker exposure to industrial hazards usually keep them out of the penal realm-making it difficult to even imagine that one could proceed otherwise. Corporate interests uphold the idea that they should have a right to immunity, and that any attempt to hold them accountable for dangerous working conditions is economically unsound.

This paper focuses on three loopholes in legal strategy that make it difficult for determined social movements and committed prosecutors to secure conviction against corporate executives suspected of negligent exposure of workers to industrial hazard, with or without resulting consequences - in other words, of "safety crime." 2 These loopholes are the following three notions: (1) that "modern" industrial risk is by essence impersonal and diluted, making the assignment of individual responsibility difficult or impossible, (2) that industrial hazard is foreign to any notion of intention, fault or responsibility, and (3) that the certainty of the causal link between exposure and damages must be established for each victim on a purely individual, rather than statistical, basis. While the first two loopholes hold for fatalities, injuries and disease alike, the third is specific to multifactorial disease with long latency periods, such as cancer.

What is at stake here is the possibility of ever securing a conviction in the event of negligent exposure to occupational hazards. This paper shows how prosecution sought to circumvent these loopholes in the Eternit Turin asbestos maxi-trials, with more or less success. Although there appear to be solid legal workarounds for the first and second loophole, the third one remains problematic. Criminal law is ill-equipped to deal with multifactorial diseases with long latency periods, despite the fact that the latter have become the main killers in the workplace during the twentieth century. ${ }^{3}$ This calls for urgent political and legal imagination in order to ensure that a vast territory of potentially criminal behavior, harming workers around the world, does not remain forever off-limits for criminal justice.

The Eternit maxi-trials were closely followed by victims of occupational disease and corporate executives around the world. They were held in Turin and Rome between 2009 and 2014 and opposed the People of Italy to the former managers and owners of four asbestos manufacturing plants in Italy. ${ }^{4}$ This unique case came as the crowning moment of four decades of Italian legal activism around the preservation of worker health. It was a rare moment in which the possibility of criminal punishment for worker injury and disease suddenly became credible and challenged the long-standing practices and representations that usually keep such offenses out of the criminal realm. As a sociologist with the French National Center for Scientific Research, I had the opportunity to study the Eternit case from a historical, sociological, and legal perspective, through interviews in Turin and Casale Monferrato with many of the main protagonists, the study of documents used in the proceedings, as well as the analysis of the decisions. 
In the Eternit case, the defendants argued that their past behavior could not and should not be criminally prosecuted. This is the specific quality of safety crime, and more generally of white-collar crime: defense strategies can focus as much on exculpation - "the defendant did not do this" - as on keeping the case out of the criminal realm- "even if the defendant did do this, this is no matter for criminal justice." Such a strategy is facilitated when it can rely on legal loopholes - areas that have been insufficiently explored by legal scholarship and political imagination, roads less taken, unthought of or unthinkable solutions. Social science has pinpointed the challenge of "undone science" in public health cases. ${ }^{5}$ This paper draws attention to the undone political and legal reflection about solutions which would make criminal law fully applicable to hazards that are constitutive of our times.

\section{The Noncriminalization of Safety Crimes: An Overview}

"Safety crimes" have been defined as "acts of commission or omission by employers that imperil the health and/or safety of their employees." 6 They are acts that would usually be considered criminal if they occurred outside of the work environment - or in another country. ${ }^{7}$

According to Sutherland, exposure to workplace hazards is a case in point of "white-collar crime," that is, "illegal behavior [which] receives the attention of administrative commissions and of courts operating under civil or equity jurisdiction," the famous case of the Hawks Nest tunnel, near Gauley Bridge, Virginia, which was drilled in 1930-1931: “. . . out of 1500 workers on this project, an appalling number, estimated variously between the limits of 200 and 500, died from silicosis while many others were permanently injured."9 This did not result in convictions, although it clearly contradicted the time's medical knowledge and existing prevention technology. ${ }^{10}$

For historical reasons, exposure to industrial hazard and ensuing damages have been managed by institutions other than criminal justice. The fact that these institutions have claimed longstanding "ownership"11 of this public problem hinders any attempt at criminalization.

Labor inspectorates were created in most industrialized countries during the nineteenth century to control the adequacy of working conditions. Their monopoly on these issues generally did not result in more criminalization. They ended up concentrating their attention on formal rather than substantial violations, because of a structural shortage of inspectors, which did not allow for a thorough examination of the reality of working conditions in every factory. As British criminologist and historian W.G. Carson writes,

. . . inspectors rapidly begin to evolve routine modes of inspection which, without abdicating from the attempt to regulate, acknowledge the power differentials 
permeating their relationship with the employers, tolerate certain levels of violation as acceptable, and institutionalize alternative methods of control. ${ }^{12}$

Carson describes the circular process through which labor inspections comfort the "conventional" (i.e., noncriminalized) nature of factory crime:

... once a "low-profile" approach to legal proceedings has been institutionalized within an enforcement agency, a sort of circular process ensues: the crime remains conventional because it is only infrequently prosecuted, and is infrequently prosecuted because it is conventional. ${ }^{13}$

As of the second half of the nineteenth century and on into the twentieth, workers' compensation schemes were implemented in Switzerland, Austria, England, Russia, Italy, France, Japan, Canada, and some U.S. states. ${ }^{14-16}$ Most of these schemes carry the implicit idea that "professional risk" is an unavoidable feature of modernity and that therefore, the modern way of governing this risk is financial compensation by a state-guaranteed insurance plan, rather than litigation based on the supposedly outdated notions of fault and responsibility. Berman calls this system the "compensation-safety apparatus" that purports to "solve" the issue of occupational exposure through the verification of procedural conformity and the allocation of fixed-rate compensation. ${ }^{17}$

In the United States, the creation of the Occupational Safety and Health Administration (OSHA) in the 1970s made the compensation-safety apparatus more complex. Rosner shows that the effect of the criminal penalties laid out by OSHA was to stifle any legal enterprise purporting to treat occupational fatalities or disease as a crime. ${ }^{18}$ Conversely, the weakening of OSHA in the 1980s did incite some state attorney generals to launch criminal action in such cases. A few landmark decisions around 1990 tended to safeguard the idea that OSHA criminal penalties did not overlap with state prosecutors' efforts, though a cursory overview of American case law seems to show that this new trend quickly died down afterward, perhaps because prosecutors became stymied by the high bar for proving intent to harm. ${ }^{19,20}$

There is a "relatively unorganized resentment of the public" 21 against the "slow violence" of exposure to industrial hazard. ${ }^{22}$ Leftist and progressive political or union-based movements that denounce and improve working conditions have often been reluctant to call for penal repression because of their anti-prison mind-set. For example, in 1970s France, Maoist groups inspired by Foucault had some difficulty advocating that criminal employers receive prison sentences. ${ }^{23}$

The ideological and financial proximity between business interests and the state is another reason for noncriminalization. Exposure to industrial hazard and occupational injury are presented as a set of facts that cannot be punished without great prejudice to the entire economy. As Fauconnet, a student of Durkheim, writes in his sociological study of responsibility: "societies tend to 
punish, but they also resist punishing." 24 The reasons not to punish stem not so much "from the consideration of the crime, as from the consideration of the patient who would have to bear the brunt of punishment." 24 Some groups benefit from a kind of immunity because of their financial or political clout. Likewise, Sutherland writes that "the persons who define business practices as undesirable and illegal are customarily called 'communists' or 'socialists' and their definitions carry little weight." 25 In his study of occupational danger in British North Sea oil rigs, Carson points out the "political economy of speed," 26 in other words, the geopolitical and economic rationale of the oil rush, which justifies the disregard for basic safety regulation. In the case of Canada, Bittle and Snider consider that the "deep-seated socio-political commitment to capitalism" is behind the difficulty to criminalize safety crimes. ${ }^{27}$

\section{The Eternit Asbestos Maxi-Trials in Turin: A Case Study}

Founded at the beginning of the twentieth century, Eternit SpA (Societa per azioni-a form of corporation in Italy) was an Italian group, with headquarters in Genoa, that manufactured products (roof tiles, tubes) based on the Eternit asbestos-cement patent. The last factory closed in 1986. At the beginning of the 2000s, the office of the Turin public prosecutor started a lengthy investigation focused on the top managers (coming after previous investigations and trials). This resulted in a criminal trial, commonly known in Italy as the Eternit maxitrial (maxiprocesso is a word usually used for antimafia trials), held between 2009 and 2011 before in Turin. The "maxi" prefix refers to the number of victims, the high status of the defendants and the length of the trial. Two wealthy industrial magnates, the Swiss Stephan Schmidheiny and the Belgian Louis de Cartier de Marchienne, identified as the de facto top executives and owners of the four Italian plants considered, were charged with two counts of felony: omission of safety measures (Article 437) and intentional exposure to an environmental disaster (Article 434). An estimated figure of 2987 victims was quoted during the trial, 1800 of which were already deceased, mainly from lung cancer, pleural mesothelioma, or asbestosis, diseases that are classically found in excess in populations exposed to asbestos. Most of the diseased were former workers, but some were relatives of workers (who described being exposed to asbestos brought home on work overalls), and some just neighbors of the plant, with no family connection to the work force (exposed to airborne asbestos around the premises).

Dozens of lawyers represented the defendants and the civil parties. Asbestos victims and activists from all over the world followed the proceedings from abroad. In February 2012, more than a thousand of them flocked to hear the verdict, taking up most of the rooms of the Turin courthouse (the decision was transmitted and translated in real time). 
In the first decision, ${ }^{28}$ the judges pronounced both defendants guilty on both counts and sentenced them to sixteen years imprisonment each. An appeals trial was held, also in Turin, and on 3 June 2013, the judges sentenced the Swiss defendant to eighteen years imprisonment, considering that there were aggravating circumstances concerning the moral element (intention) of the crime. ${ }^{29}$ The Belgian defendant died a few weeks prior to the decision. On 19 November 2014, Italy's supreme court, the Corte di Cassazione, canceled the Court of Appeal decision, ${ }^{30}$ on the basis of the statute of limitations. The judges decided that the expression "disaster" referred only to the exposure, rather than to the ensuing epidemic of asbestos-related disease, which is still ongoing. They also considered that the disaster had ceased the day the last factory had closed, at the end of the 1980s. This reasoning was hotly disputed among legal scholars and activists, because to this day the pollution is still present in the environment, long after the factories have closed.

\section{Criminalizing Worker Injury: A Turinese Tradition}

Italy experienced a consistent mobilization from the 1960s onward which aimed at criminal prosecution of corporate injury and killings. The intensity and scope of this mobilization - which brought together organized labor, environmental activists, physicians, and legal professionals - was probably unrivaled in contemporary European or American history.

The genesis of the case is best followed through the biography of one man, former Turin prosecutor Raffaelle Guariniello. Born in 1941 in a small village of the province of Alessandria (thirty miles from the asbestos plant of Casale Monferrato), the son of a tailor, he studied in Turin and entered the judicial profession in 1967, where he represented the state as pretore then procuratore. ${ }^{31}$ In the 1960s, Turin was alive with intense intellectual and political debates about new ways of improving working conditions. ${ }^{32}$ They were driven by strong unions in the Fiat Mirafiori plant (the largest automobile plant in Europe at the time) and the Farmitalia chemical factory, with the support of physicians such as the influential Ivar Oddone. In the name of health, workers demanded the right to decide themselves, and collectively, how work should be organized and their health protected, summarizing this under the slogan non-delegazione. ${ }^{33}$ One national translation of this was the 1970 Statute of Workers which provided, in its Article 9, that workers were in charge of controlling, through their union representatives, that the laws on working conditions and health prevention were being enforced.

Rather than a unilateral worker victory, this statute was the "outcome of contradictory political and economic forces" ${ }^{34}$ which continued to run through industrial workplaces after it. Within occupational medicine, a conservative streak continued to resist the more progressive new generation. In the world of law, organizations such as Magistratura Democratica (founded in 1964) 
pushed legal professionals to go beyond symbolic proclamations and better understand the experience of manual workers. In 1974, the Supreme Council of Magistrates (CSM) organized a conference entitled "Expanding our focus to occupational disease," in partnership with the Italian General Confederation of Labour (CGIL) union of metallurgists. Guariniello helped organize the first criminal trials around questions of occupational disease. The IPCA factory in Ciriè, nicknamed the "Cancer Manufacturing Plant" (fabbrica del cancro) because of the bladder cancer epidemic among its workers, ${ }^{35}$ was the subject of an important 1977 decision of the Turin Tribunal, which sentenced the company's managers to six years imprisonment for manslaughter. It was the first time in contemporary Italian history that occupational manslaughter was punished by a prison sentence.

A few years later, Guarinello published a book in which he laid out his plan to make sure that an "elementary legal principle" would be respected at last: "that sickness which is caused by intentional exposure to toxic substances in the work environment can be construed as one of the crimes - injury or homicidepunishable by all Penal Codes since 1859."36 The prosecutor wrote that legal professionals should learn from similar cases abroad such as Minamata Disease in Japan, should partner with epidemiologists to advance scientific knowledge on the causes of disease and death among workforces and communities, and should try to move up the hierarchy of the incriminated plants so as not to punish (only) middle management for decisions that are often taken at the highest level.

Immediately after publishing this book, Guariniello created an "Observatory of Occupational Cancer" managed directly by the Turin procura. Located in the historic center of Turin, permanently staffed with five to ten people under the guidance of an epidemiologist, it identified potential cancer clusters from physicians' reports and hospital records, prompting investigations and many subsequent trials.

Since the 1970s, Guariniello had started investigating negligent exposure in the Eternit asbestos factories. This had already resulted in trials in which the responsibility of lower level managers had been recognized. In 1996, the trial of the managers of the Italian Asbestos Society (SIA), a medium-sized asbestosprocessing company, was held in Turin. Nine of them were found guilty for the diseases and deaths of workers. During the same period, the Porto Marghera trial opened in Venice in $1998 .{ }^{37}$ The plant was a huge petrochemical one, located across the laguna from the touristic city. Prosecution linked the diseases of hundreds of workers to their occupational exposure to vinyl chloride monomer (VCM).

\section{Producing Organizational Opacity}

To whom can one, and should one, assign responsibility for industrial disease? The dominant notion is that modern industrial organizations are intrinsically 
too complex for notions of individual responsibility. "Accidents happen," 38 as if industrial hazard was some unavoidable feature of nature, on par with extreme weather or geologic events. Even the founding father of the study of white-collar crime, Sutherland, supports the idea:

the old employers' liability laws, which were based on the principle of individual responsibility, broke down because responsibility for industrial accidents could not be located. Workmen's compensation laws were substituted, with their principle that the industrial establishment should bear the cost of industrial accidents. ${ }^{39}$

The specific protections granted over time to corporations, such as the "corporate veil," certainly reinforced this difficulty to assign individual responsibility, producing a "diffusion of responsibility." 40 Tombs shows that in the United Kingdom, the 2007 "Corporate Manslaughter and Corporate Homicide Act" made the "corporate veil" more difficult to pierce. While this action was done in an apparent trade-off with the possibility of prosecuting the corporation itself, records show that there have been very few successful prosecutions and acquittals in the following decade, and that large corporations seem particularly protected from criminal justice. ${ }^{41}$

The Eternit case suggests that the difficulty to assign responsibility does not only stem from exogeneous, "modern" factors such as the complexity of industrial organizations and the specific nature of contemporary industrial disease. It can also be explained by active, endogeneous efforts from would-be defendants to make it difficult to assign individual responsibility.

For example, the Swiss industrial magnate Stephan Schmidheiny was prosecuted for his alleged responsibility as owner and top manager of the Italian Eternit factories between the mid-1970s and their closing at the end of the 1980s. The prosecutor's investigation uncovered elements that suggest that Schimdheiny then started preparing for the possibility of a criminal trial, probably because the issue had recently become highly litigious in countries such as the United States. ${ }^{42}$ Between 1984 and 2005, Schmidheiny continuously employed the Milan-based consulting firm of Guido Bellodi. ${ }^{4,43,44}$ Its mission, as defined through the archives that were seized in a 2005 police raid, was to contain the responsibility for exposure to asbestos in and around the Italian Eternit factories, at a level that would not imperil the Swiss defendant.

Bellodi's efforts were mirrored by other attempts to shape a morally flawless persona through biographical work. Throughout the nineteen pages of a 1991 interview to the Family Business Review, neither Schmidheiny nor his obliging sparring partner use the word "asbestos" a single time. When describing the way his father shared the family business between his two sons, Schmidheiny vaguely explains: "my older brother would handle the cement part and I would be responsible for the rest." 45 The "rest" being: asbestos. 
As Sutherland suggests, the "pyramiding of companies and juggling with corporate entities" are convenient tools to opacify individual criminal responsibility. ${ }^{46}$ In the 2010s, in its press releases responding to the various decisions, Schmidheiny's legal team invariably presented the defendant as, at most, a minority shareholder: "he never had any formal function within the Italian Eternit, he neither was owner nor member of the Board of Directors nor member of the management" 47 ; "The company [Schmidheiny] headed - SEG - merely held a stake in the publicly listed Italian Eternit SpA. In the latter's 80-year history, SEG was the largest single shareholder from 1973 to 1986 only." 48 This argument is all the more difficult to counter that the organization of the world asbestos industry is extremely complex, as illustrated by the fact that in Europe at least five companies, based in different countries, are named Eternit (after an asbestos-cement patent).

Yet, this alternate history did not hold in the face of historical inquiry. Turin associate prosecutor Sara Panelli and "white-collar-crime" sociologist Rosalba Altopiedi wrote various papers describing Schmidheiny's personal involvement in the Italian asbestos factories. ${ }^{43,44}$ Their findings played a crucial role in the proceedings. At the beginning of 2015, an English-language translation of one their articles was to be published as an e-book. Schmidheiny's legal representatives immediately challenged this publication, and the local history organization behind the translation project preferred to retract the book rather than face litigation which it could not afford. A translation was nevertheless published by the U.S. based “Asbestos Disease Awareness Organization” in 2016. ${ }^{44}$

Thus, the Turin investigations and trials defeated this containment strategy, bringing back to the forefront the asbestos past which all official biographies sought to minimize. Ironically, the Court of Appeal considered that "the methodical erasing of all traces which began in a period when [Schimdheiny] was not even suspected or tried speak to the inexcusable nature of his personal role." 49

Admittedly, the active containment strategy carried out during more than two decades forced public prosecution to rely on broad historical study, which was costly in manpower and time. Yet, prosecution showed that it was possible, through this careful study, to determine individual responsibility even in such complex organizations, confirming what has been shown for other industries by professional historians. $^{50}$

\section{No Offense Intended?}

In his study of labor inspection in nineteenth century Britain, Carson notes that factory crime is rarely "prosecuted, and when it is, this course of action is almost invariably predicated upon some rough notion of mens rea as perceived by the relevant Inspectorate." ${ }^{11}$ He suggests that an 1844 law that

remov[ed] the issue of intention from the crimes of employers [. . .] took a substantial step towards the doctrine of strict liability which sets certain crimes apart 
from "ordinary" crimes and has led many jurists to argue that such offenses should not really be regarded as criminal at all. ${ }^{52}$

In other words, the lack of intention justifies that industrial disease is not prosecuted as a crime. Conversely, securing an element of intention is a sine qua non condition to prosecute such a situation successfully.

Obviously, most employers do not wish injury or death upon their workers, except in specific situations where workers are part of a minority group which is targeted by a broader political campaign. ${ }^{53,54}$ Compensation schemes generally ignore the element of intention, and thus raising any debate about intention can seem quite exotic. When incriminated, employers usually defend themselves by stating that they followed the formal procedures of risk management over a given period. Any question about the knowledge that they may have had that these procedures were insufficient to protect workers is actively discarded by identifying "the gaps in knowledge rather than the continuities," 55 and more generally by stating that there is no reason industry should be in advance on the laws of its time.

The Eternit case did not follow the usual script: both of the charges pressed include an element of intention. Article 434 refers to "intentional disasters," while article 437 concerns "intentional removal or omission of prevention measures against occupational hazard." Public prosecution, and the judges, only included a fairly low level of intention-but intention, nonetheless.

It was in a previous, equally high-profile case that Guariniello had started crafting his legal practice concerning intention. ${ }^{56}$ During the night of 5 to 6 December 2007, a fire engulfed a production line in the ThyssenKrupp steelworks in Turin, killing seven workers. Charges were pressed against the company as well as six of its managers. In a move that surprised the Italian legal world, Harald Espenhahn, managing director of ThyssenKrupp for Italy, was charged with omicidio doloso (intentional, or fraudulent, homicide) rather than omicidio coloposo (manslaughter), which is the usual charge in such cases. Guariniello based himself on internal correspondence which showed that a few months before the Turin disaster, Espenhahn had been warned by the factory director of serious fire hazards. According to prosecution, Espenhahn was aware that there had been a similar fire in a German factory only a year earlier, but had nevertheless decided to deny the Turin director the security investments he was asking for.

Guariniello considered that there was a degree of intention in the managing director's negligence, because even though he was fully aware of the possibly tragic consequences of his decision not to act, he did not falter in his decision. The first judge followed Guariniello on this reasoning, while the Court of Appeal and the Supreme Court confirmed the condemnation for manslaughter but removed the intentional element. 
Nevertheless, the Thyssen case was the defining moment of the notion of dolo eventuale in Italian legal doctrine concerning safety crimes ${ }^{57}$-dolus eventualis in Latin, which can be translated into English as "eventual fraud." This notion is commonplace and considered unproblematic when discussing negligence while driving, which often involves showing "that a 'responsible person' would have foreseen" the negative outcome. 58 Eventual fraud was famously mobilized during the criminal trial of South African athlete Oscar Pistorius, which considered that he knew that he would kill the person (in fact, his wife) who was locked in the bathroom when he shot four rounds through the door. The Pistorius trial popularized the strange-sounding expression of "murder without intent."

Eventual fraud is about accepting risk, rather than trying to avoid it. The seven steelworkers did not lose their life to a meteor or a lightning bolt, but as a result of a chain of events which included clear decisions to act, regardless of eventually tragic consequences. This is why Guariniello considered eventual fraud an essential part of any prosecution of occupational and environmental crimes, which hinge on the notion of "permissible" or "acceptable" risk, or in other words, exposure to hazards that is balanced against profitability.

The defendants strongly opposed their depiction as willful injurers. For example, Schmidheiny's press release after the Supreme Court decision caricatured the former judges' decision to include an element of intention.

In their verdicts, they constructed a full-blown conspiracy theory and alleged that Stephan Schmidheiny was fully aware of the dangers of asbestos processing. Motivated by pure greed, he allegedly orchestrated a global campaign to deceive the public about these dangers. As the 'party actually responsible' for the Italian Eternit SpA, he was, they alleged, consciously prepared to accept the deaths of thousands of people and intentionally caused a disaster that persists to this day. ${ }^{48}$

In fact, this account was very distant from what was actually discussed in the two first trials. In the Eternit case, prosecution produced documents that showed that the Belgian defendant was present in meetings which took place in 1968, during which the scholarship of Irving Selikoff, the leading medical researcher on asbestos, ${ }^{59}$ was discussed. According to Guariniello, this showed his clear knowledge of the eventual consequences of not implementing proper cleaning, aspiration or humidification of dusty environments. As for the Swiss defendant, it was shown that he delivered a speech in Neuss, Switzerland in June 1976 in front of thirty-five top managers, during which he discussed the health consequences of exposure to asbestos. The judges considered he demonstrated his grasp of the matter, discussing asbestosis, lung cancer, mesothelioma, and referring to Selikoff's works. Yet, he did not implement all the prevention measures that were warranted. 


\section{Statistical Certainty Versus Individual Uncertainty in the Demonstration of Causality}

Can an individual's sickness be linked to a specific situation of exposure, with the degree of certainty necessary to secure criminal conviction? In the case of occupational and environmental cancer, which have come to epitomize the modern risks caused by industrial activity, most legal scholars and professionals tend to answer negatively. This is because medical science studies the causation of cancer through statistical studies on large populations: a population exposed to a potential factor is compared to a population that is not exposed to it, and correlations between the factor and the prevalence of the disease are established (or not). Epidemiological inquiry is the gold standard of medical certainty. Conversely, the knowledge on the dangerousness of a toxicant is drawn from the statistical studies that show its correlation with disease.

From these statistical results, there is no way to infer causality at an individual level - i.e., between a person's sickness and their past or present work - with the same level of certainty. In other words, it is scientifically impossible to prove that an individual would not have contracted cancer had he or she not worked in such company during such period (and been exposed to such factor). The only thing one can prove, if the exposed population is big enough, and if confounding factors are few enough, is that such determinate number of workers (or neighbors) would not have contracted cancer had they not been exposed. But in no way is it possible to determine the identity of those who, among the individuals affected by cancer today, would not have suffered the same plight in the absence of exposure. This is true even for rare forms of cancer for which only one causal agent is identified (so-called "signature cancers," such as pleural mesothelioma, caused by asbestos, or liver angiosarcoma, caused by vinyl chloride monomer). Quid of exposure to asbestos or vinyl chloride monomer at home? Hence, statistical certainty, when addressing causality at a population level, cannot be translated into individual certainty.

This scientific fact is a clear challenge to criminal justice. In some situations, it is possible to determine the number of victims that have contracted disease because of exposure to an industrial hazard, but it is not possible to judge this exposure and its effects, because the victims' identity cannot be established. This was the case in the town of Casale Monferrato, where the flagship of Italian Eternit factories was located. Longitudinal epidemiological studies ${ }^{60}$ based on many decades of cumulative research (often paid for by the prosecutor's office) showed for example that male workers in the Casale Monferrato plant were 32 times more likely to have died from pleural cancer, 27.3 times more likely to have died from peritoneum cancer, 2.3 times more likely to have died from lung cancer, and 545 times more likely to have died from asbestosis, than the general male population of the Piedmont region. As for female workers in the plant, they were 2.27 times more likely to have developed ovary cancer than the female 
reference population. However, it is impossible to establish who exactly, among the thousands of victims of these diseases listed on local registers, would not have contracted the disease had he or she not worked in the factory, or lived near it.

The Italian legal tradition had a way around this problem until the beginning of the 2000s. This doctrine, known as the "increase of mortality criteria," stated that a person's sickness could be blamed on a defendant if it was demonstrated that the latter's behavior had increased the risk, for the exposed subject, of contracting this sickness. However, in 2001, a leading Italian legal scholar published a study in which he refuted this doctrine which had led to all previous sentences for manslaughter in relation to occupational disease. ${ }^{61,62}$ Stella criticized this reasoning because it did not protect the rights of defense. He considered it did not abide by the classic penal criteria that the incriminated behavior should be a sine qua non condition for the individual damage. Stella argued that it was necessary to demonstrate, beyond reasonable doubt, for each person, that their sickness would not have occurred if the subject had not been exposed to the harmful working conditions. In other words, he compelled prosecution to demonstrate what is impossible to demonstrate.

In their 2001 decision on the Porto Marghera case, the judges in Venice followed this and acquitted all defendants. This reasoning was confirmed by Supreme Court decisions in 2002. From that point on, demonstrating a general causal link between exposure to a hazard and a type of disease was no longer enough; individual causality had to be demonstrated also through counterfactual reasoning, with a probability "near 100\%." With the new doctrine, occupational and environmental cancer had suddenly become off-limits for criminal justice.

Public prosecution came up with a new strategy in the Eternit maxi-trials. It implied prosecuting exposure as a crime in itself, regardless of its potential consequences. For both of the charges pressed in the Eternit maxi-trials, the crime solely consists in the exposure to the impending risk. Thus, according to article 434, "renting out buildings on the verge of collapsing and other intentional disasters," the fact that the building eventually collapses and harms its inhabitants is considered an aggravating circumstance, not a necessary condition. The "and other intentional disasters" addition provides for extensions to similar situations. Prosecution considered that this was the case for the asbestos plants: a clear danger potentially harming an indeterminate number of people, to which top executives exposed the work force as well as the surrounding population.

The advantage of this strategy, from prosecution's point of view, was that it no longer implied demonstrating causality on an individual scale. Demonstrating exposure was relatively easy, drawing on testimony from former workers, neighbors, managers, and on past labor inspection and company archives. Epidemiological results were also used to prove exposure, with the following reasoning: the fact that there was an excess of victims of disease among workers 
and neighbors of factories (when compared to a reference population) proved that there has been an abnormally high exposure to the risk factor.

The prosecutor's office repeatedly stated that exposure charges were the most efficient way to create a link between criminal justice and prevention of occupational hazards, as they could be pressed without having to wait decades for widespread damage to be verified. Prosecution also wished to play on the expressive function of punishment: ${ }^{63}$ the sentences linked to each of the charges were severe enough (three to twelve years for Article 434, added up with three to ten years for Article 437) for them to look similar to the ones pronounced for manslaughter, and therefore, potentially, for victims to feel that their plight had been taken seriously, and, possibly, for employers to consider that they had to start complying with these laws.

The defense lawyers tried to shift the debate back to the more common terrain of individual causality. During the first trial, one of the defense experts reviewed the particulars of many cases of Eternit Casale workers who had been officially recognized as having an occupational disease and listed what he considered were inaccuracies and approximations in individual files. His ultimate aim was to invalidate the epidemiological reasoning according to which the excess of victims proved the exposure to asbestos.

The judges resisted this push back toward individual causality. The Court of Appeals decision, in particular, justifies the prosecution of exposure by equating it with the demonstration of what it calls "collective causality." Establishing collective causality means showing that,

had the defendants not acted in a way which contributed to the diffusion of asbestos in the workplace and the surrounding environment, the thesis stating that the population considered in the epidemiological study was exposed to danger would no longer stand. ${ }^{29}$

Behind this complex legalese was the idea that "collective causality" was synonymous, in the end, with the demonstration of exposure to toxic working conditions.

In a twenty-page section, the decision refers to the commanding inspiration of the French historical school known as the Annales, founded by Marc Bloch and Lucien Febvre, to justify the use of certain tools which can "bring to light [. . . the slow evolution of certain phenomena," and can "make certain aspects emerge that lack, by essence, immediate empirical evidence," in other words that are invisible to the naked eye. ${ }^{29}$ The Annales historians used quantitative datasets on long periods to get to this hidden stratum of reality. For the Turin judges, epidemiology and the concept of collective causality will do the job. In the Eternit case, victims "when considered individually are not relevant, they only are when considered collectively." ${ }^{29}$ They consider that epidemiological inference must be used to grasp "the influence of specific risk factors" and cannot be challenged by 
individual inaccuracies (such as the ones pointed out by defense consultants), as long as this error is not systematically biased in one direction. ${ }^{29}$

There were important drawbacks to this legal strategy. Some scholars considered it a kind of renunciation, as it meant focusing on the public disorder of exposure to hazard, while ignoring (for technical reasons) the greater public disorder of mass disease. ${ }^{64}$ Another legal drawback, which would prove fatal, was that by dealing with exposure, this strategy focused on events which had occurred many decades ago, rather than on a series of diseases which continue to be diagnosed to this day. This paved the way for the final annulment on the basis of the statute of limitations.

\section{Conclusion}

The Eternit maxi-trials showed that despite organizational complexity, individual corporate responsibility could be determined through careful historical research. They also were an important moment in the global reflection on intentionality in worker exposure to occupational hazards: as French philosopher Jean-Paul Sartre said in 1970 after the accidental death of sixteen miners in the north of France, in such cases "the agency of fate has a human face" (cette fatalité a un visage d'homme). ${ }^{65}$ Finally, the Eternit maxi-trials paved the way for a legal solution to the problem of causal uncertainty concerning individual victims, in cases where the causal link to exposure can only be determined on a population, statistical level.

Despite victims' and prosecutors' thriving imagination and willpower, the Italian criminal code is still ill-equipped to deal with cancer, that is, the kind of occupational (and, one may add, environmental) damage which seems paradigmatic of our times. This is true a fortiori for most other countries, much less advanced in this discussion.

All concerned protagonists must dismiss, once and for all, the dream of establishing the causal link between exposure and disease on an individual level, and devise new tools to criminalize exposure and damages, based solely on statistically established facts.

Since 2007, Italian legal scholar L. Masera has been pushing to import a doctrine of "alternative verification," developed in German public health trials, and applying it to victims of occupational disease. ${ }^{66}$ His reasoning goes as follows: Epidemiology can prove that there have been victims within a certain population. What it cannot do is identify by name the victims who would have not have fallen ill or died, had they not been exposed. But is this identification by name necessary? Masera considers that criminal prosecution needs only to establish the number of victims, not their identity. However, this doctrine is still considered very audacious by the mainstream of the Italian legal profession. In any case, the future of the judicial treatment of industrial hazards is not determined so much by what is possible, as by what is considered suitable and timely. 
This paper suggests that the notions of legal possibility and opportunity to criminalize are difficult to dissociate.

In Italy, there is no respite in the struggle to prosecute and judge these crimes. In the so-called Eternit bis case, Guariniello filed murder charges against Schmidheiny in summer of 2014, a few months before the annulment of the Eternit decisions and his retiring, concerning more than 200 deaths. The matter then went through almost four years of travel through the Constitutional Court and the Court of Cassation, on such issues as whether Schmidheny could be charged with murder, or whether the charges should be reduced to manslaughter (they were eventually ordered reduced) and whether it was "double jeopardy" to try Schmidheiny for the same acts, as his lawyers put it (that appeal was refused by the courts). What resulted was that there are to be four separate trials in which Schmidheiny will be tried for manslaughter, one in each region of Italy in which the deaths occurred (Turin, Naples, Vercelli, Reggio Emilia). The Turin trial was the first one to start in April 2018. The judgment will probably be announced in 2019 (followed months later by the court's "Motivation" in which the legal reasoning behind the verdict is explained). The Naples trial started in April 2019. It will be interesting to analyze the decisions when they are published, and eventually see what new solutions have been devised in the battle for corporate accountability in safety crimes.

\section{Acknowledgments}

I thank the journal's anonymous reviewers for their helpful comments, and in particular for suggesting the final paragraph. I thank Emmanuel Henry and Annie Thébaud-Mony for initially supporting this project, and all the people in Turin and Casale Monferrato who introduced me to the particulars of the Eternit case during my travels in 2012-2014, in particular Rosalba Altopiedi, Daniela Degiovanni, Dario Magnani, Sara Panelli, Niccola Pondrano, and Benedetto Terracini. Thank you also to Sida Liu and Céline Bessière for their comments on previous drafts of this paper.

\section{Declaration of Conflicting Interests}

The author(s) declared no potential conflicts of interest with respect to the research, authorship, and/or publication of this article.

\section{Funding}

The author(s) disclosed receipt of the following financial support for the research, authorship, and/or publication of this article: This research was made possible through funding from the French National Center for Scientific Research and the French National Agency for Research.

\section{ORCID iD}

Pascal Marichalar (D) https://orcid.org/0000-0002-4263-1703 


\section{References}

1. Bittle S and Lippel K. Recent trends in corporate criminal liability. Policy Pract Health Saf 2013; 11: 1-7.

2. Tombs S and Whyte D. Safety crimes. Cullompton: Willan, 2007.

3. Rosner D and Markowitz G. The trials and tribulations of two historians: adjudicating responsibility for pollution and personal harm. Med Hist 2009; 53: 271-292.

4. Castleman B. Criminality and asbestos in industry. New Solut 2017; 26: 557-580.

5. Frickel S, Gibbon S, Howard J, et al. Undone science: charting social movement and civil society challenges to research agenda setting. Sci Technol Hum Values 2010; 35: 444-473.

6. Tombs S and Whyte D. Safety crimes. Cullompton: Willan, 2007.

7. Michalowski RJ and Kramer RC. The space between laws: the problem of corporate crime in a transnational context. Soc Probl 1987; 34: 34-53.

8. Sutherland E. White collar-crime: the uncut version. New Haven: Yale University Press, 1983, p. 6.

9. Sutherland E. White collar-crime: the uncut version. New Haven: Yale University Press, 1983, p. 152.

10. Rosner D, Markowitz G. Deadly dust: silicosis and the on-going struggle to protect workers' health. Ann Arbor: University of Michigan Press, 2005.

11. Gusfield JR. The culture of public problems: drinking-driving and the symbolic order. Chicago: University of Chicago Press, 1981.

12. Carson WG. The conventionalization of early factory crime. Policy Pract Health Saf 2005; 3: 118.

13. Carson WG. The conventionalization of early factory crime. Policy Practice Health Saf 2005; 3: 121.

14. Moses $\mathbf{J}$ and Rosenhaft E. Moving targets: risk, security, and the social in twentiethcentury Europe. Soc Sci Hist 2015; 39: 25-37.

15. Rosental PA and Thomann B. Silicosis and "silicosis": minimizing compensation costs; or, why occupational diseases cost so little. In: Rosental PA (ed) Silicosis: a world history. Baltimore: Johns Hopkins University Press, 2017, pp. 105-140.

16. Howard C. Workers' compensation, federalism, and the heavy hand of history. Stud Am Polit Dev 2002; 16: 28-47.

17. Berman D. Death on the job: occupational health and safety struggles in the United States. New York: Monthly Review Press, 1978.

18. Rosner D. When does a worker's death become murder? Am J Public Health 2000; 90: 535-540.

19. People v Hegedus, 432 Mich 598, 1989.

20. People v Chicago Magnet Wire Corp., 126111 2d 356, 1989.

21. Sutherland E. White collar-crime: the uncut version. New Haven: Yale University Press, 1983, p. 59.

22. Nixon R. Slow violence and the environmentalism of the poor. Cambridge: Harvard University Press, 2011.

23. Bérard J. Tordre ou briser le bâton de la justice? Les mouvements de l'après-68 et les illégalismes des dominants, entre justice populaire et refus de la pénalité (1968-1972). Champ pénal/Penal field, https://journals.openedition.org/champpenal/8418 (2013, accessed 9 May 2019). 
24. Fauconnet P. La responsabilité. Etude de sociologie. Paris: Felix Alcan-Classiques des Sciences Sociales, 1920, p. 285.

25. Sutherland E. White collar-crime: the uncut version. New Haven: Yale University Press, 1983, p. 250.

26. Carson WG. The other price of Britain's oil: safety and control in the North Sea. Oxford: Martin Robertson, 1981.

27. Bittle S and Snider L. Law, regulation, and safety crime: exploring the boundaries of criminalizing powerful corporate actors. Can J Law Soc 2015; 30: 459.

28. Turin Tribunal, N. 5219/09 R.G, February 13, 2012.

29. Court of Appeal of Turin, Third Criminal Court N. 5621/2012, June 3, 2013.

30. Corte di Cassazione, Penale Sent. Sez. 1 Num. 7941, November 19, 2014.

31. Papuzzi A. Il giudice. Le battaglie di Raffaelle Guariniello. Rome: Donzelli, 2011.

32. Carnevale F and Baldasseroni A. A history of union struggles for control of the work environment in Italy. Int J Occup Environ Health 2005; 11: 6-11.

33. Reich MR and Goldman RH. Italian occupational health: concepts, conflicts, implications. Am J Public Health 1984; 74: 1031-1041.

34. Calavita K. Worker safety, law, and social change: the Italian case. Law Soc Rev 1986; 20: 191.

35. Benedetto P, Masselli G, Spagnoli U, et al. La fabbrica del cancro. L'IPCA di ciriè. Turin: Einaudi, 1976.

36. Guariniello R. Se il lavoro uccide: riflessioni di un magistrato. Turin: Einaudi, 1985, p. 15.

37. Masera L. Évidence épidémiologique d'une augmentation de la mortalité et responsabilité pénale. À la Recherche D'une Qualification Pénale Pour Une Nouvelle Catégorie Épistémologique. Revue Des Sciences Criminelles 2015; 3: 553-572.

38. Behrent M. Accidents happen: François Ewald, the "antirevolutionary" Foucault, and the intellectual politics of the French Welfare State. J Modern Hist 2010; 82: 585-624.

39. Sutherland E. White collar-crime: the uncut version. New Haven: Yale University Press, 1983, p. 61.

40. Croall H. White collar crime: criminal justice and criminology. Buckingham: Open University Press, 1992, pp. 12-13.

41. Tombs S. The UK's corporate killing law: un/fit for purpose? Criminol Crim Justice 2018; 18: 1-18.

42. Barnes J. In defense of asbestos litigation: judicial policy-making in a world of uncertainty, second bests and shared policy-making responsibilities. Law Soc Inq 2009; 34: 5-30.

43. Altopiedi R and Panelli S. Il grande processo. Quaderni di Storia Contemporanea 2011; 51: 17-77.

44. Altopiedi R and Panelli S. The great trial. California: Asbestos Disease Awareness Organization, 2016, http://www.asbestosdiseaseawareness.org/archives/38113

45. Lank AG. A conversation with Stephan Schmidheiny. Fam Bus Rev 1991; IV/2: 211.

46. Sutherland E. White collar-crime: the uncut version. New Haven: Yale University Press, 1983, p. 38.

47. Incomprehension at Verdict Against Stephan Schmidheiny. Media release published on February 13, 2012, www.stephanschmidheiny.net.

48. Sarasin EM and Di Amato A. Stephan Schmidheiny Acquitted. Media release published on November 19, 2014. 
49. Castleman B. Criminality and asbestos in industry. New Solut 2017; 26: 569.

50. Markowitz G and Rosner D. Deceit and denial: the deadly politics of industrial pollution. Berkeley: University of California Press, 2002.

51. Carson WG. The conventionalization of early factory crime. Policy Pract Health Saf 2005; 3: 119.

52. Carson WG. The conventionalization of early factory crime. Policy Pract Health Saf 2005; 3: 120.

53. McCulloch J. South Africa's gold mines and the politics of silicosis. Suffolk: James Currey, 2012.

54. Hachtmann R. Fordism and unfree labour: aspects of the work deployment of concentration camp prisoners in German industry between 1941 and 1944. Int Rev Soc Hist 2010; 55: 485-513.

55. Rosner D and Markowitz G. The trials and tribulations of two historians: adjudicating responsibility for pollution and personal harm. Med Hist 2009; 53: 288.

56. Thébaud-Mony A and Lafforgue F. Industrial crimes and the criminal justice system: experiences from continental Europe. Policy Pract Health Saf 2013; 11: 8-89.

57. Viganò F. Il dolo eventuale nella giurisprudenza più recente. Diritto Penale Contemporaneo. https://www.penalecontemporaneo.it/d/2951-il-dolo-eventuale-nellagiurisprudenza-piu-recente (2014, accessed 9 May 2019).

58. Bittle S and Snider L. Law, regulation, and safety crime: exploring the boundaries of criminalizing powerful corporate actors. Can J Law Soc 2015; 30: 451.

59. McCulloch $\mathbf{J}$ and Tweedale G. Science is not sufficient: Irving J. Selikoff and the asbestos tragedy. New Solut 2007; 17: 293-310.

60. Terracini B. Witness report to the Turin Tribunal, Relazione presentata il 13 dicembre 2010. Proc. 24265/04 R.G.N.R.

61. Stella F. Giustizia e modernità: la protezione dell'innocente e la tutela delle vittime. Milano: Giuffrè, 2001.

62. Masera L. La Malattia Professionale e il Diritto Penale. Diritto Penale Contemporaneo, https://www.penalecontemporaneo.it/d/1007-la-malattia-professio nale-e-il-diritto-penale (2011, accessed 9 May 2019).

63. Feinberg J. The expressive function of punishment. Monist. 1965; 49: 397-423.

64. D'Ambrosio L. Amiante et droit pénal: quelques réflexions sur l'affaire Eternit de Turin. Revue de Droit du Travail 2014; 6: 418-421.

65. Sartre JP. Premier procès populaire à Lens. In: Sartre JP. Situations VIII. Paris: Gallimard, 1971, pp. 319-331.

66. Masera L. Accertamento alternativo ed evidenza epidemiologica nel diritto penale. Gestione del dubbio e profili causali. Milano: Giuffrè, 2007.

\section{Author Biography}

Pascal Marichalar is a sociologist with the French National Center for Scientific Research. He studies occupational health and safety and environmental pollution, in France, Italy and the United States. His latest book is a study of industrial disease and the struggle for justice of contemporary glassworkers in France. 